Chipping Sparrow

(Spizella passerina)

Although the Chipping Sparrow is a common victim, Friedmann (1963) stated that he knew of no records of nest desertion due to the presence of cowbird eggs. On May 29, 1969 we discovered a nest of this species containing one sparrow egg and one cowbird egg. A visit to the same nest on June 5 revealed only the cowbird egg in the nest and it was cold. Kondla found three cowbird eggs in a Chipping Sparrow nest which contained no sparrow eggs at Norman Lake on June 19, 1968. The nest was one foot up in a white spruce sapling. The eggs were cold when found.
Chestnut-collared Longspur

(Calcarius ornatus)

Friedmann (1963) states that observations of parasitism in nests of this species have been reported regularly only from North Dakota, and that most of these were in the 1890 's. One of the most recent observations is again from North Dakota on June 19, 1933 by George C. Whithey. Kondla found a Chestnut-collared Longspur nest on May 27, 1967 at Lake Newell which contained two longspur eggs and two cowbird eggs. This appears to be one of the most recent observations and the first record from Alberta.

\title{
SOME BREEDING ASPECTS OF HERRING GULLS AT KAWINAW LAKE, MANITOBA
}

by Kees Vermeer, Canadian Wildlife Service, Edmonton

Incidental to a study of egg laying chronology and food habits of Herring Gulls (Larus argentatus) during May and June, 1971 on two small islands in Kawinaw Lake, $52^{\circ} 50^{\prime} \mathrm{N}$; $99^{\circ} 29^{\prime} \mathrm{W}$, Manitoba, data were collected on egg size, egg laying intervals, incubation periods, clutch size and hatching success. Little is known about these subjects for inland populations of this species in North America.

Egg measurements were taken of the first (I egg), second (II egg) and third eggs (III egg) laid in 39 clutches and are compared with those of Herring Gull eggs measured in Europe
(Table 1). The third egg was on the average smaller than the first two eggs laid, a common phenomenon in gulls (Vermeer, 1969). Egg dimensions at Kawinaw Lake appear similar to those in Denmark and Norway, but dissimilar to those in England. According to Barth (1967), who extensively measured body parts of Herring Gulls in northern Europe, the British population is a separate form of that in Fen. noscandia. No body measurements of Herring Gulls were made at Kawinaw Lake.

Egg laying intervals and incubation reriods were determined for clutches

Table 1. Mean length and width of eggs I, II and III in $\mathrm{mm}$ in Herring Gulls.

\begin{tabular}{|c|c|c|c|c|c|c|c|c|}
\hline \multirow{2}{*}{ Authority } & \multirow{2}{*}{ Location } & \multirow{2}{*}{$\begin{array}{c}\text { No. of } \\
\text { clutches } \\
\text { measured }\end{array}$} & \multicolumn{3}{|c|}{$\begin{array}{l}\text { Mean length of eggs } \\
\text { in } \mathrm{mm}\end{array}$} & \multicolumn{3}{|c|}{ Mean width of eggs } \\
\hline & & & I & II & III & $\mathrm{I}$ & II & III \\
\hline Harris, 1964 & England & 100 & 68.7 & 68.7 & 66.5 & 48.3 & 48.4 & 46.3 \\
\hline Paludan, 1951 & Denmark & 57 & 72.4 & 72.1 & 69.2 & 50.6 & 50.5 & 49.2 \\
\hline Barth, 1967 & North Norway & 59 & 73.7 & 73.5 & 71.4 & 50.6 & 50.7 & 49.5 \\
\hline Barth, 1967 & Middle Norway & 76 & 72.8 & 72.3 & 70.2 & 49.4 & 49.7 & 48.3 \\
\hline Barth, 1967 & South Norway & 18 & 73.2 & 72.2 & 71.2 & 50.2 & 50.5 & 49.5 \\
\hline This study, 1971 & Canada & $39^{*}$ & 72.7 & 73.7 & 71.9 & 50.1 & 50.5 & 49.3 \\
\hline
\end{tabular}

* Standard errors for the mean length and width of the I, II and III eggs were $0.6,0.3,0.5,0.3,0.7$ and 0.4 respectively. 
Table 2. Egg-laying intervals between successive eggs in clutches and incubation periods* of Herring Gulls, 1971.

\begin{tabular}{|c|c|c|c|c|c|c|c|}
\hline Egg-laying intervals, days & 1 & 2 & 3 & Incubation period, days 24 & 25 & 26 & 27 \\
\hline No. of laying intervals & 1 & 43 & 18 & No. of incub't'n periods 1 & 7 & 24 & 1 \\
\hline $\begin{array}{l}\text { Mean } \pm \mathrm{SE} \text { of laying } \\
\text { interval }\end{array}$ & 2.3 & \pm & 0.6 & $\begin{array}{l}\text { Mean } \pm \text { SE incubation } \\
\text { period }\end{array}$ & 25.8 & \pm & 0 . \\
\hline
\end{tabular}

* Incubation periods are the intervals between laying and hatching of the third egg.

Table 3. Comparison of hatching success between Herring Gull clutches initiated during the first and second half of the egg-laying season.

\begin{tabular}{lcccc}
\hline Time of clutch & No. & No. & \multicolumn{2}{c}{ Hatched } \\
$\quad$ initiation & clutches & eggs & No. eggs & $\%$ \\
First half of season & 107 & 321 & 226 & 70.4 \\
Second half of season & 54 & 151 & 94 & 62.2 \\
Total & 161 & 472 & 330 & 69.9 \\
\hline
\end{tabular}

Table 4. Comparison of hatching success between different clutch sizes of Herring Gulls in the second half of the egg laying season.

\begin{tabular}{ccccc} 
Clutch size & No. clutches & No. eggs & No. eggs Hatched & $(\%)$ \\
3 & 44 & 132 & 89 & 67.4 \\
2 and 1 & 10 & 19 & 5 & 26.3 \\
\hline
\end{tabular}

which were visited daily during laying and hatching. The mean laying interval of 62 known intervals was 2.3 days and the mean incubation period of 33 known periods was 25.8 days (Table 2). The mean incubation period and standard error for 67 known periods for a Herring Gull population in Denmark was $27 \pm 0.08$ days, which is significantly different.

The mean clutch size for 102 clutches initiated to May 17, the mean date for clutch initiation, was 3.00. That for 82 clutches started after May 17 was $2.74 \pm 0.06 \quad$ (SE). Coulson (1966) found that female Black-legged Kittiwakes (Rissa tridactyla) with greater breeding experience, and which retained their mate of the previous breeding season, laid on the average earlier and had larger clutches. Perhaps the same is true for Herring Gulls.

The hatching success of 161 Herring Gull clutches was 69.9 percent (Table $3)$. The difference in hatching success between clutches initiated during the first and second half of the season was not significant $(p=0.08)$. Table 4 relates hatching success to clutch size for clutches initiated during the second half of the egg laying season. Smaller clutches produced significantly fewer chicks than larger clutches ( $p$ 0.05).

Of 142 eggs which did not hatch, 97 were addled, 37 disappeared or were preyed upon, and eight chicks died during hatching. As no predators other than Herring Gulls were observed near the nesting islands it is thought that those gulls were responsible for missings eggs and eggs which were preyed upon.

\section{LITERATURE CITED}

Barth, K. E. 1967. Egg dimensions and laying dates of Larus marinus, $L$. argentatus $L$. fuscus and $L$. canus. Nytt Magasin for Zoologi, $15: 1-34$.

Barth, K. E. 1967. Standard body measurements in Larus argentatus, $L$. fuscus, $L$. canus and L. marinus. Nytt Magasin for Zoologi, $14: 1-83$.

Coulson, J. C. 1966. The influence of pair-bond and age on the breeding biology of the kittiwake gull Rissa tridactyla. Journ. Animal Ecology, 35 :269-279.

Harris, M. P. 1964. Aspects of the breeding biology of the gulls Larus argentatus, L. fuscus and $\mathrm{L}$. marinus Ibis, $106: 432-456$.

Paludan, K. 1951. Contributions to the breed. ing biology of Larus argentatus and Larus fuscus. Vidensk. Medd. fra Dansk Naturh. Foren., $114: 1-128$.

Vermeer, K. 1969. Egg measurements of California and Ring-billed Gull eggs at Miquelon Lake, Alberta in 1965. Wilson Bull. $81: 102+103$. 